\title{
経時的に雪質の変化した屋根上積雪と塗装鋼板との摩擦特性 EFFECT OF TEMPORAL CHANGES IN THE QUALITY OF SNOW ON FRICTION BETWEEN SNOW AND STEEL SHEETS ON THE SLOPED ROOF
}

\author{
高 倉 政 寛*, 伊 東 敏 幸**, 苫米地 司*** \\ Masahiro TAKAKURA, Toshiyuki ITO and Tsukasa TOMABECHI
}

\begin{abstract}
In this study, we investigated the effect that the quality of accumulated snow on the snow's resistance to sliding. First, we observed changes in the quality of snow that had accumulated on the roof of a building. It was found that the particle size of the snow increased to approximately $2 \mathrm{~mm}$ after one week and that the water content of the snow increased. Next, experiments were conducted to determine the effect that particle size of snow on a sloped roof has on the snow's resistance to sliding. The results showed that the resistance to sliding decreased as the particle size of snow increased (i.e., as the snow became more granular). The effect of particle size on the snow's resistance also depended on the degree of snow melting. From the facts described above, it is possible to utilize the effect of particle size on the snow's resistance for control of snow sliding on a sloped roof.
\end{abstract}

Keywords : Sloped roof, Snow load, Snow sliding, Snow quality, Roofing material 勾配屋根, 積雪荷重, 滑雪, 雪質, 屋根暺材

\section{1.はじめに}

多雪地域における建築物は，大きな荷重として作用する屋根上積 雪によって構造的な制約を受けている。勾配屋根における屋根上樻 雪をみると, 滑雪現象が頻繁に発生して図一1に示すような荷重状 況となる場合も多いり。現行の建築基準法においても, 屋根勾配が $30^{\circ}$ 以上の場合では勾配による屋根上積雪荷重の低減が認められてい る。さらに近年, 膜材料を屋根莫材に用いた大型ドームでは実験・ 調查に基づいた検討によって屋根勾配 $25^{\circ}$ 以上の部位における屋根 上積雪荷重の低減を行っている例もある2)。しかし，1981年の「56豪 雪」による建築物の被害をみると, 勾配屋根を持つ建築物において も顕著な滑雪現象が発生せずに長期間にわたり屋根上に雪が堆積 し, 崩壊に至った例も多〈みられる3〉。このように, 勾配屋根を持つ 建築物でも滑雪現象の発生状況が大きく異なっている。従って, 勾 配による屋根上積雪荷重の低減を行う場合には, 個々の建築物の屋 根構法や使用する屋根莫材に対応した滑雪特性を検討することが重 要となる。1993年に改訂された日本建築学会建築物荷重指針におい ても, 実験や調査に基づいた検討によって十分に信頼性のある雪処 理手法が可能な場合は, その設計荷重に制御積雪荷重を用いて, 屋 根上積雪荷重の低減が出来るように改訂された4)。屋根上積雪荷重 の制約を大きく受ける大空間構造物が多雪地域にも建設されるよう になった現状を考えると, 屋根勾配を利用して屋根雪を滑落処理さ せて屋根上積雪荷重を制御する方法は経済的にも有意と言える。こ の場合, 滑雪現象を支配する諸抵抗力を適切に評洒し, 制御積雪荷 重を設定しなければならない。これらの諸抵抗力に関する既往の研
究をみると, 自然雪を用いた屋外実験結果から雪質の違いによって 諸抵抗力が変化することが確認されている5゙。筆者らの研究におい ても，雪質の評価指標の一つとなる雪の含水率の違いによって摩擦 抵抗力が大き〈変化することが明らかになっているあ。このように， 雪質の違いによって諸抵抗力が変化することが確認されているもの の, 既往の研究では屋根莫材の表面性状に主眼が置かれていたこと

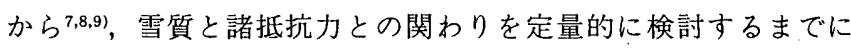
至っていない。

屋根上に降り積もった雪の滑雪に至るまでの時間的な状況をみる と，屋根上に降り積もった雪は，その直後に滑雪現象が発生するこ とが稀で，数時間あるいは数日間にわたって屋根上に堆積した後に

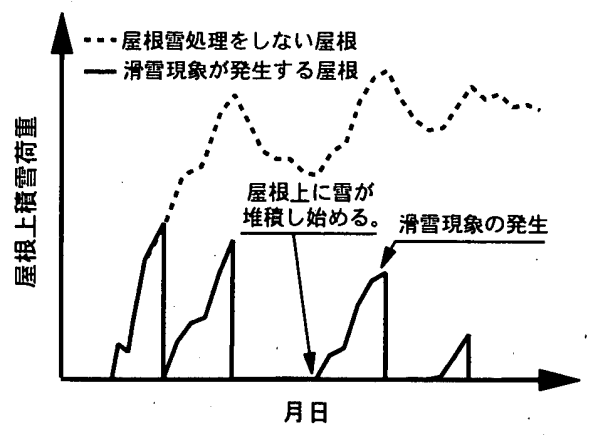

図一 1，勾配屋根における屋根上樻需荷重の荷重状況
${ }^{*}$ 北海道工業大学大学院 大学院生·修士(工学)

** 北海道工業大学建築工学科 講師 $\cdot$ 博士 (工学)

*** 北海道工業大学建築工学科教授・工博
Graduate Student, Graduate School of Hokkaido Inst. of Tech., M. Eng. Lecture, Dept. of Architecture, Hokkaido Inst. of Tech., Dr. Eng. Prof., Dept. of Architecture, Hokkaido Inst. of Tech., Dr. Eng. 
滑雪するのが一般的である ${ }^{10)}$ 。この堆積期間中に屋根面に接する雪 は, 外気温の変動や小屋裏からの伝熱によって生ずる雪の焼結や融 解によって，雪質が新雪からしまり雪，ざらめ雪等へと変態してゆ く。この状況は屋根雪の断面観測でも確認されている ${ }^{11) 。 こ の よ j ~}$ に，屋根面に接する雪質は屋根上に堆積している数日間において不 変ではなく,数日間であってもその物性が大きく変化することから， 滑雪抵抗力を適切に評価する場合，雪質に関わる要因を無視できな w。

これらのことから本研究では，勾配屋根における制御積雪荷重の 設定に関する基礎資料を得ることを目的とし，屋根雪の雪質変化が 滑雪時に作用する摩擦抵抗力に及ほす影響を実験的に検討した。始 めに，滑雪現象に影響を及ほす雪物性を整理するとともに，実際の 建築物における屋根雪の雪質変化を観測した。この結果から，屋根 面に雪が堆積してから数日内に起こり得る雪質変化をモデル化した 実験を行い，屋根雪の経時的な雪質変化（粒径の変化，融雪による 水分の発生）に伴う屋根葺材との摩擦抵抗力について評価した。

\section{2. 滑雪現鼠に䦙わる抵抗力と炎の諸要因}

屋根雪の滑雪現象を支配する抵抗力は，連続的な屋根雪の破断を 阻止する雪塊相互の破断抵抗力と，屋根雪と屋根幕材との間に発生 する滑雪界面抵抗力の 2 つに大別できる。前者の破断抵抗力には積 雪の引張およU゙せん断抵抗力などがあり，これらの抵抗力は屋根形 状の工夫，屋根面の温度分布を均一にすること等で低減あるいは解 除することが可能である ${ }^{12)}$ 。後者の滑雪界面抵抗力には, 滑雪開始へ の抵抗力として作用する凍着抵抗力および静摩擦抵抗力, 滑雪持続 への抵抗力として作用する動摩擦抵抗力がある。このうち凍着抵抗 力が作用する氷点下の条件では，その抵抗力が極めて大きな值とな るため, 滑雪現象の発生を期待できない13)。従って, 外気温の変動や 小屋裏からの伝熱などで涷着抵抗力が解除された状態に作用する抵 抗力は, 静・動摩擦抵抗力となる。このように, 屋根幕材と屋根雪 との静・動摩擦抵抗力は，滑雪現象を定量的に評洒する有効な指標 と言える。静・動摩擦抵抗力は，屋根雪と屋根龩材との界面に発生 する抵抗力であることから，屋根莫材の表面性状および屋根雪の雪 質がこれらの $2 つ の$ 抵抗力を大きく支配している。ここで, 静・動 摩擦抵抗力に影響する屋根驀材および屋根雪の諸要因について整理 すると図一2になる。図のように，静・動摩擦抵抗力に影響する屋 根草材の表面性状には，表面粗さおよび撥水性が挙げられ，その中 でも表面粗さの影響は大きい。一方，静・動摩擦抵抗力に影響する 屋根雪の性状には，雪塊の含水率，密度およじ硬度，あるいは雪粒 の形や粒径が挙げられる。このうち，密度は雪の粒径に依存し，硬 度は低温下での温度に依存する。雪粒の形状は雪の焼結過程で球形 化し，雪塊の含水率は滑雪界面の水量よりも摩擦に対する影響が小 さい。従って，これらの物性の中で滑雪抵抗力に大きく影響する項

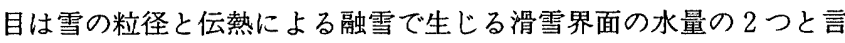
える。これらのことから，滑雪現象を定量的に評価するためには， 屋根莫材の表面性状が及ぼす静・動摩擦抵抗力への影響について検 討を行うと同時に, 雪粒径の変化や融雪による水分の発生が, 静・ 動摩擦抵抗力へ及ほす影響についても十分に検討しておく必要があ る。

\section{3 . 屋根雪の経時的な雪質变化}

屋根上に堆積した雪は，その雪質が時間の経過に伴って変化し， 一般には新雪からさらめ雪へと変態してゆく。このような雪の変態

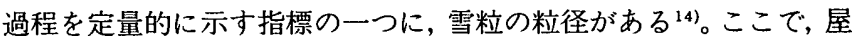
根雪が屋根上に堆積した状態で数日間経過する際の変態状況を確認 するため，実際の建築物における屋根面温度を測定し，その結果を 基に滑雪界面付近の屋根雪における雪粒径が経時的に変化すること を検証すると以下のようになる。

屋根面温度の測定は，札幌市手稲区に建設された一般的な戸建住 宅を对象に1997年 2 月に行った。对象とした住宅屋根は, 踷消し塗 装鋼板を草いた勾配屋根で小屋裏換気が行われており, 天井と小屋裏 との間にグラスウール200 $\mathrm{mm} の$ 断熱が施されている。室内温度は約 $18^{\circ} \mathrm{C}$ で推移するように暖房が行われている。屋根面温度は棟と軒の中央 部における屋根草材の裏面に熱電対を貼り付けて10分毎に測定した。

連続的な降雪があった期間における住宅各部の温度推移をみると 図一 3 となる。なお，図示した期間内に滑雪現象は発生していない。 図のように，2月16日の降雪以降は屋根面に積雪があり，それ以前 は氷点下であった屋根面温度が約 $0.5^{\circ} \mathrm{C}$ まで上昇している。積雪があ る期間内の小屋裏温度をみると, 外気温の変化に影響を受けて推移 している。これに対し，屋根面温度は外気温の影響を殆ど受けない で, 常に0.5ㅇ 前後の温度を保ったまま推移している。屋根面温度が

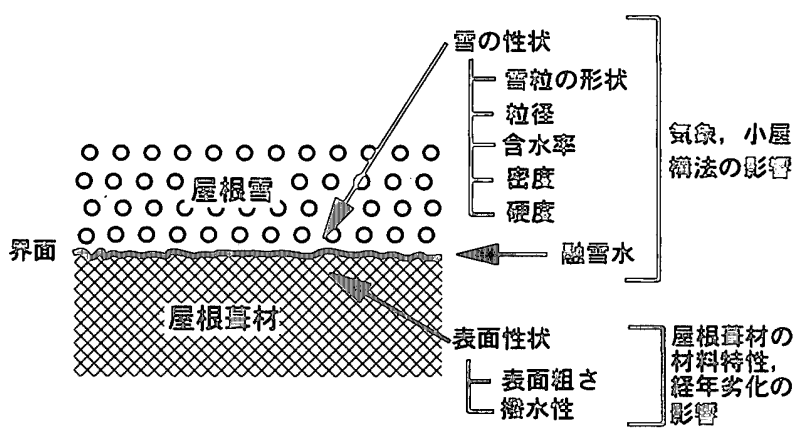

图一2 滑雪現象に関わる屋根蕉材および屋根雪の要因

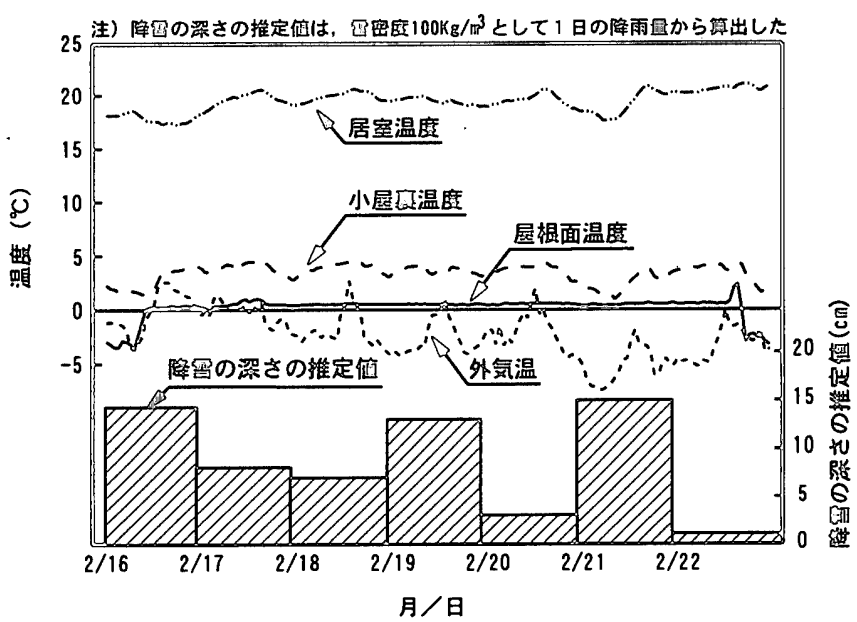

图一3 連続的に降雪のあった期間における住宅各部の温度推移 
このような温度推移となる要因は, 屋根面に積雪した雪の断熱作用 が影響しているためである。この温度条件で経過した屋根雪を 2 月 23日にスケール付きの100倍ルーぺで観察すると, 滑雪界面付近の雪 は 1 2mmの粒径を持つざらめ雪へと変態していた。このような雪 の変態については，温風を直接吹き付ける膜構造物で降雪後24時間 以内に約 $1 \mathrm{~mm}$ まで粒径変化した事例もあり ${ }^{11)}$ ，屋内からの伝熱は 雪粒径の変化に大きな影響を及ぼしていると考える。

ここで, 雪の変態に伴う粒径変化の要因を扱った研究を基に雪粒

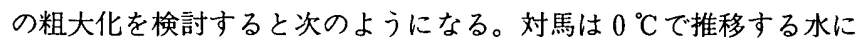
浸った新雪の平均粒径が 130 時間で $0.3 \mathrm{~mm}$ から $1.1 \mathrm{~mm}$ へ粗大化す ることを観測し，粒径（mm）の増加が時間（hour）の1/3乗に比例 することを明らかにしている15)。さらに福沢らは, 昼間の日射によっ て暖められた新雪層が $1.5^{\circ} \mathrm{C} / \mathrm{cm}$ 程度の温度勾配で冷やされた場 合, 98 時間で0.199mm から $0.779 \mathrm{~mm}$ へ雪粒径が粗大化することを 明らかにしている ${ }^{16)}$ 。これらの研究と先に示した観察結果を併せて 考察すると, 屋根面付近の積雪は屋内からの伝熱によって多くの水 を含んだ状態になれば，その雪質の変態が進行することになる。屋 根雪の経時に伴う雪粒径の変化は, 屋根面への伝熱が大きいほど著 しくなると考之られるが，暖房を行っている一般的な住宅では， 3 〜 4 日程度で $1 \mathrm{~mm}$ 程度, 1 週間以上となれば $2 \mathrm{~mm}$ 程度にまで粗大 化すると考えられる。このように雪粒径の粗大化は, 屋根荣材の劣 化などのように年単位で変化する材料特性と異なり, 数日間で急速 に進行する。従って, 屋根雪の滑雪性状を評価する場合は, 経時的 に変化する雪粒径を考慮した検討が必要と言える。

\section{4. 雪粒径の異なる雪水体の滑雪特性}

屋根面付近の雪は時間の経過に伴って, その粒径が大きく変化す ることから，この雪質変化に対応した雪水体の滑雪性状を評価して おく必要がある。そのため, 本研究では降雪直後から数日経過に至 るまでの粒径を想定した雪を対象に, 表面粗さの異なる屋根莫材を 用いて摩擦抵抗力を測定した。また，外気温上昇などに伴う摩擦界 面の融雪は，滑雪現象に大きな影響を及ほすをと考之られるため，摩 擦抵抗力の測定時には, この融雪過程を考虑した温度条件としてい る。なお, 既往の研究から静摩擦抵抗力と動摩擦抵抗力との関係は ほぼ比例関係にあることから ${ }^{9}$, 本研究では動摩擦抵抗力を滑雪抵 抗力の指標とした。

\section{1 実験の方法}

動摩擦抵抗力の測定に用いる雪水体は，粒径が経時的に粗大化す る過程の雪を用いた。雪質の違いに関して一般に用いられている分 類は，表一 1 の左欄の通りであり，同分類中で霜ざらめ雪に関して は屋根面付近の雪質と異なる分類となることから，本研究では同表 右闌に示すような雪質の雪水体を対象とした。表のように, 融解水

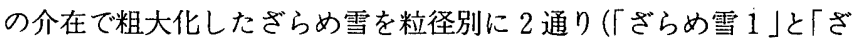
らめ雪 $2 」)$ 設定し，これに「新雪」と「しまり雪」を加えた合計 4 種類の雪質における動摩擦係数を測定した。測定に用いた雪水体は, 厳寒期の地上積雪層から採取した。また，粒径を持たない水ブロッ クについても測定した。なお，採取した雪の主な粒径はスケール付 きの100倍ルーぺで測定した。

測定の対象とした屋根草材は，滑雪性状に影響が大きい要因であ る表面粗さの異なるものとした。その試料は, 表一 2 に示すような
表面粗さを持つ屋根用塗装鋼板 6 種類である。なお，屋根葺材の撥 水性を示す接触角 $\theta$ は, 試料の違いによって若干のバラツキを示す ものの,いずれも $\theta=90^{\circ}$ 以下の值を示していることから,これらの試 料は, 付着した水分がぬれ広がりやすい性質を持つ屋根蒙材と言える。 動摩擦係数の測定は低温室内で水平滑雪装置》を用いて実施し た。この係数は試料上に重量が $28.8 \mathrm{kgf}$ (雪密度 $100 \mathrm{~kg} / \mathrm{m}^{3} て ゙ 20 \mathrm{~cm}$ の 降雪があったことを想定）とした $12 \times 12 \mathrm{~cm} の$ 雪水体ブロックを設 置し, $6 \mathrm{~mm} / \mathrm{sec} の$ 速度で水平滑動させたときの摩擦抵抗力から算出 した。図一 4 に動摩擦係数の測定手順を示す。図のように，屋根雪 の滑雪現象を想定すると, 屋根雪と屋根茸材との滑雪界面状態は, 水点下における乾燥状態から融雪過程における湿潤状態まで考えら れる。このことから, 屋根雪と屋根草材が共に氷点下で乾燥してい

表ー1 一般的な雪質分類と本研究で用いた雪水体

\begin{tabular}{|c|c|c|c|}
\hline \multicolumn{2}{|c|}{ 一般的に用いられている雪實の分類 ${ }^{14)}$} & \multicolumn{2}{|c|}{ 本研究て用いた雪氷体 } \\
\hline 名称 & 特徽 & 呼称 & 主な粗径 $(\mu \mathrm{m})$ \\
\hline 新雪 & $\begin{array}{l}\text { 降って間もない期間の雪で, 構成粒 } \\
\text { 子は, 多かれ少なかれ結晶形を保存 } \\
\text { している。 }\end{array}$ & 新雪 & $10 \sim 100$ \\
\hline \multirow[t]{2}{*}{ しまり雷 } & \multirow{2}{*}{$\begin{array}{l}\text { 降雪後数日経ち, 構成粒子が丸みを } \\
\text { おびた雪。粒子同土の結合も発達し, } \\
\text { 全体としてきめ細かくしまった感じ } \\
\text { を呈する。粒径は, } 0.3 \sim 0.6 \mathrm{~mm} \\
\end{array}$} & しまり雪 & $100 \sim 500$ \\
\hline & & & \\
\hline \multirow[b]{2}{*}{ 霜さららめ雪 } & \multirow{2}{*}{$\begin{array}{l}\text { 温度勾配のために, 内部に霜の結晶 } \\
\text { が成長した雪。粒子は鲜やかな結晶 } \\
\text { 形を示し, 粒径は } 1 \text { 的に達する } \\
\text { こともある。 }\end{array}$} & टらめ残 & $500 \sim 1000$ \\
\hline & & ざらめ雪 2 & $1000 \sim 2000$ \\
\hline さらめ掣 & $\begin{array}{l}\text { 融解水の介在で生じる粗い感じの雪。 } \\
\text { 粒径は普通 } 1 \text { ～} 3 \mathrm{~mm} \text { あり，一粒一 } \\
\text { をはつきりと見分けることができる。 }\end{array}$ & 氷プロック & - \\
\hline
\end{tabular}

表一2 本研究で用いた屋根用塗装鋼板の表面性状と試料 CODE

\begin{tabular}{c|c|r|r}
\hline 試料CODE & $\begin{array}{c}\text { 中心線平均粗さ } \\
\operatorname{Ra}(\mu \mathrm{m})\end{array}$ & $\begin{array}{c}10 \text { 点平均粗さ } \\
\operatorname{Rz}(\mu \mathrm{m})\end{array}$ & $\begin{array}{c}\text { 蒸留水との接触角 } \\
\theta\left({ }^{\circ}\right)\end{array}$ \\
\hline 試料 $\mathrm{A}$ & 0.33 & 1.40 & 72.3 \\
\hline 試料 $\mathrm{B}$ & 0.52 & 2.97 & 75.4 \\
\hline 試料 $\mathrm{C}$ & 1.44 & 12.10 & 75.4 \\
\hline 試料D & 2.29 & 16.20 & 84.6 \\
\hline 試料 $\mathrm{E}$ & 3.20 & 23.07 & 62.5 \\
\hline 試料 $\mathrm{F}$ & 4.08 & 26.13 & 68.9 \\
\hline
\end{tabular}

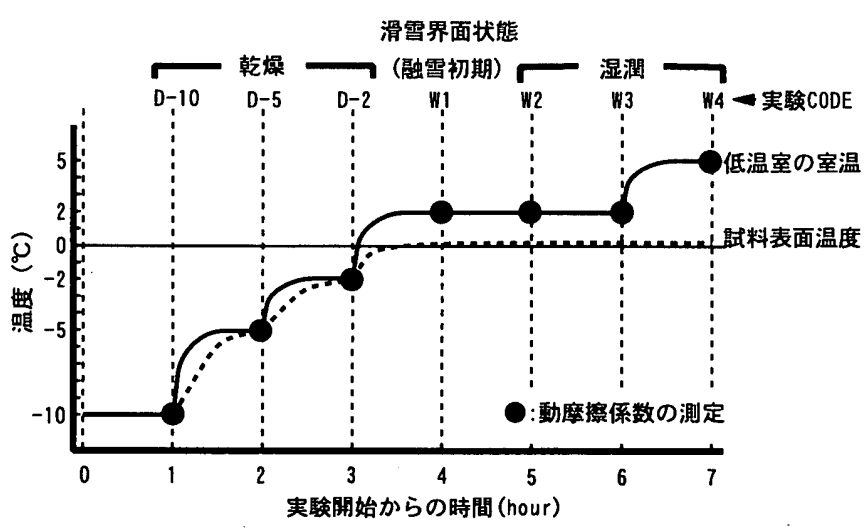

図一４動摩擦係数の測定手順と滑雪界面状態 
る状態を想定して，低温室および試料表面温度がともに $-10^{\circ} \mathrm{C} の \mathrm{D}$ -10,- $5{ }^{\circ} \mathrm{C} の \mathrm{D}-5$ および- $2{ }^{\circ} \mathrm{C} の \mathrm{D}-2$ の 3 通りを測定した。そ の後, 低温室の温度を上昇（試料表面温度は+0.5 ${ }^{\circ} \mathrm{C}$ 前後）させて, 屋根雪が融雪してゆく融雪初期の過程 W1を想定した測定を行っ た。なお，新雪およびしまり雪における W1の状態を観察すると，屋

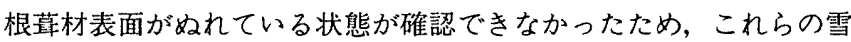
質におけるW1では，融雪水が滑雪界面を湿潤させるにまでは至っ ていない状態と言える。W1の測定後, 融雪によって滑雪界面が湿潤 してゆく状態を想定して，その状態を経過時間別にW2〜W4の 3 通 り測定した。これら動摩擦係数の測定は, 同一条件で 3 回行い, そ の平均值で評価した。なお，測定值のバラツキは土15\%以内であっ たので,雪質および滑雪界面状態の違いによる評価は可能と考之る。

\section{2 結界および考察}

(1) 動摩擦係数の測定結果

滑雪界面の状態と動摩擦係数との基本的な関係を図一 5 に示す。
図のように, 滑雪界面が乾燥した状態の場合における動摩擦係数は, $\mathrm{D}$-10から D-2へと温度が上昇しても, 若干小さくなる程度で顕 著な変化はみられない。また, 試料に用いた屋根草材の表面粗さの 違いによる動摩擦係数の変化が小さい。これに対し, 融雪初期を経 て滑雪界面が湿潤した状態になると, 動摩擦係数は急激な增加傾向 を示した後，十分な湿潤状態であるW4になると減少する傾向を示 す。湿潤状態では，表面粗さが及ぼす動摩擦係数の差が顕著であり， 表面粗さ (10点平均粗さ $R z)$ が $12.0 \mu \mathrm{m}$ 以上となる試料 $\mathrm{C}$ と $\mathrm{E}$ は,

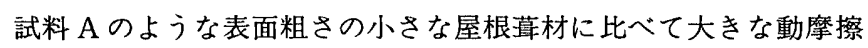
係数を示す傾向がみられた。動摩擦係数の変化を雪質の違いからみ ると，湿潤した状態における動摩擦係数の最大值はしまり雪が最も 大きく, 次に新雪, ざらめ雪 1 , ざらめ雪 2 , 水ブロックの順とな る。このように, 屋根雪と屋根莫材との動摩擦係数は, 屋根菆材の 表面粗さのみではなく，滑雪界面の湿潤状態および雪質の違いに よって顕著な差を示す。
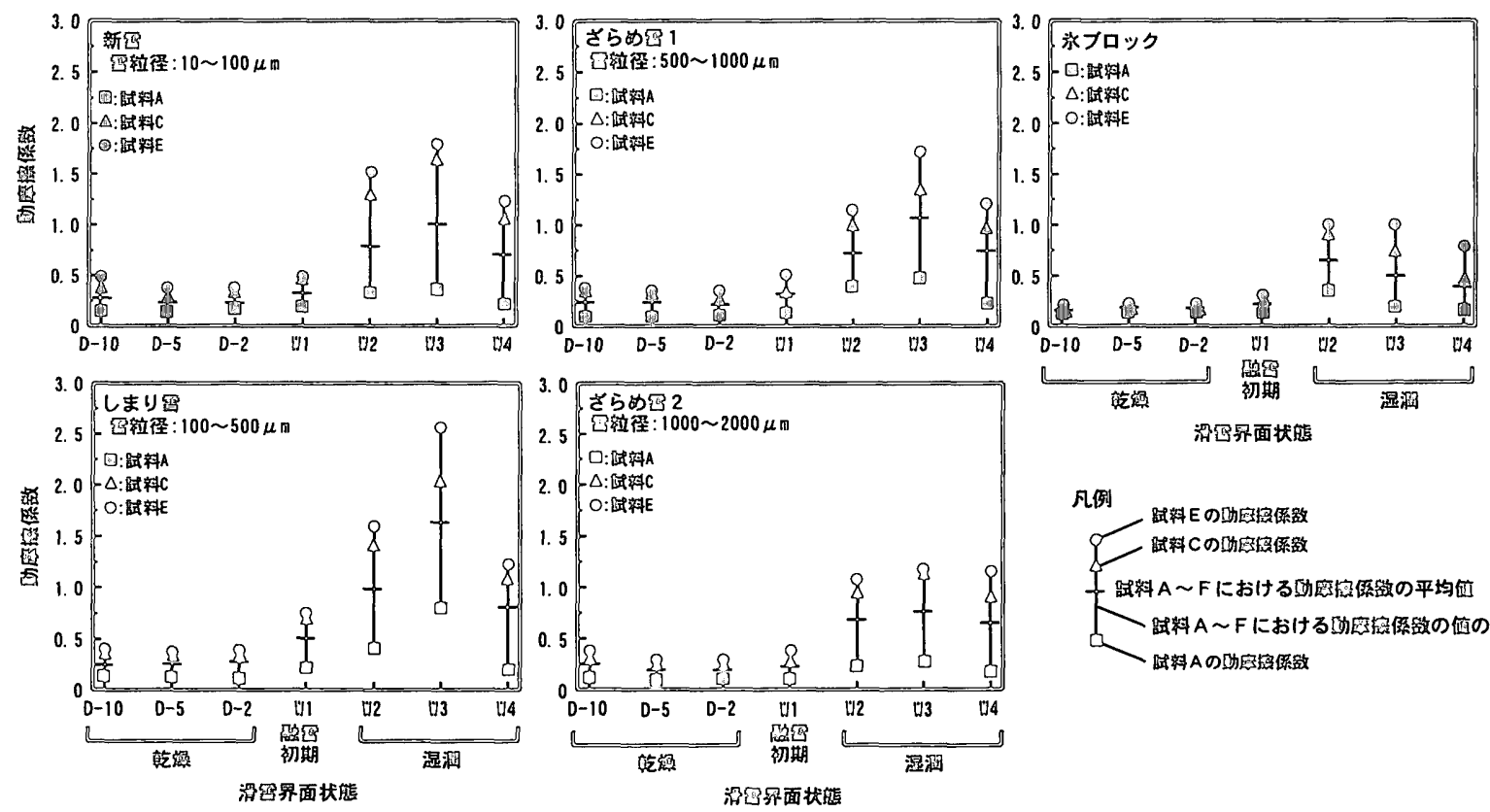

凡例

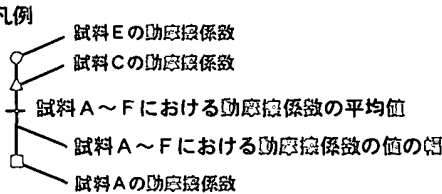

图一 5 滑雪界面状態と動摩擦係数との関係
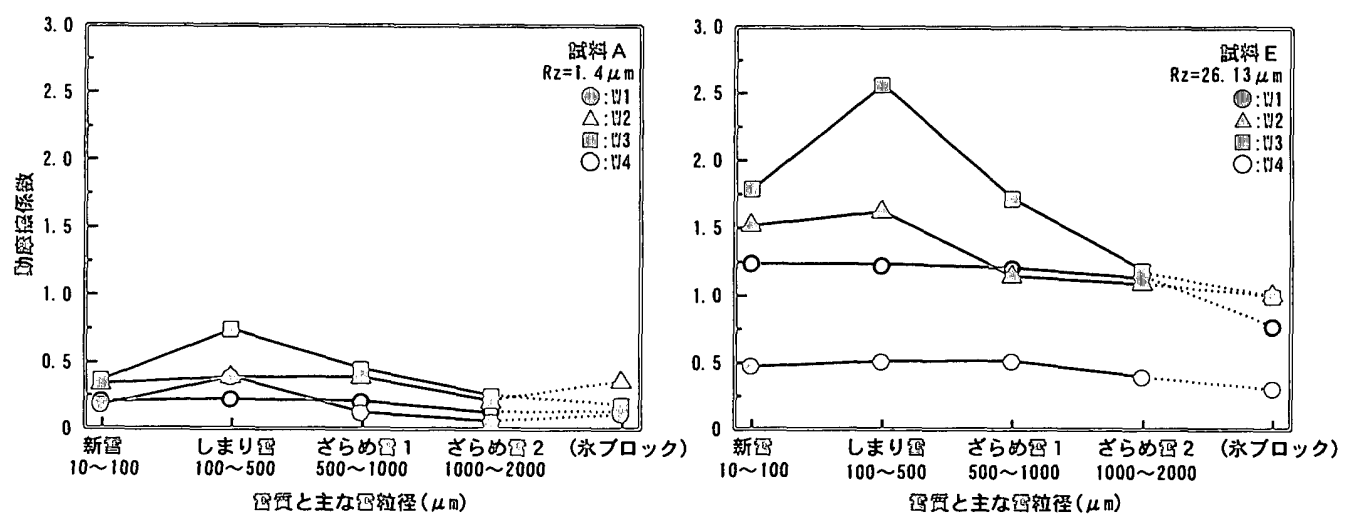

図一 6 雪粒径と動摩擦係数との関係 
雪質の影響が顕著にみられた融雪初期の状態 $\mathrm{W} 1$, 滑雪界面が湿 潤状態であるW2からW4における雪粒径と動摩擦係数との関係を みると困一 6 となる。なお，この図は表面粗度の異なる 2 試料につ いて示してある。困のように，平滑表面の試料 A および粗い表面を 持つ試料 $\mathrm{E}$ の両試料において, その動摩擦係数は雪粒径が 100 ～500 $\mu \mathrm{m}$ で最も大きくなり，その粒径以上になると減少する傾向を示す。 滑雪界面状態別にみると, W1から W3へと滑雪界面が湿潤化するに 伴って雪粒径が動摩擦係数へ及ぼす影響が顕著になり，それ以上の 湿潤状態であるW4になると雪粒径による違いが小さくなる。この 傾向は，しまり雪からざらめ雪 2 への粒径変化において顕著であっ た。

試料に用いた屋根草材の表面粗さ $R z$ と動摩擦係数との関係を, 最も大きな動摩擦係数を示した雪質であるしまり雪についてみると 図一7となる。なお，この図は動摩擦係数が急激な増加傾向を示し たW1からW3の状態について示してある。図のように，融雪初期の 状態であるW1では $R z$ が $12 \mu \mathrm{m}$ の試料 Cにおいて最も大きな動摩 擦係数を示すものの，屋根莫材の表面粗さが摩擦係数に及ぼす影響 が小さい。その後 W2の状態になると，Rzが $15 〜 23 \mu \mathrm{m}$ で動摩擦係 数が最大となる傾向を示す。さらに，融雪が進んだ界面状態 W3で

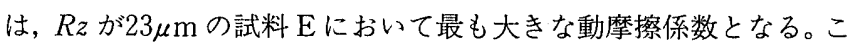
のように，滑雪界面の湿潤化が進行するに伴って動摩擦係数へ及ぼ す表面粗さの影響が顕著になると同時に，動摩擦係数が最大となる 表面粗さが大きくなる傾向がみられた。

(2) 動摩擦抵抗力に影響する諸要因の考察

降雪によって屋根面に堆積した雪は，その直後に滑雪することが 稀であり，数時間あるいは数日後に滑雪現象が発生する。すなわち， 滑雪現象が発生した場合における屋根雪は，しまり雪やざらめ雪の ように変態した雪質であり,新雪での滑雪現象の発生は考えにくい。 ここで，前述の図一6で示した粒径 $100 \sim 500 \mu \mathrm{m}$ (しまり雪) 以上の 雪質で動摩擦係数が減少する傾向，および動摩擦係数が最大となる 表面粗さが湿潤状態に影響されることの要因について考えると次の ようになる。

屋根雪と屋根草材との湿潤状態における摩擦現象には, 雪粒と屋 根葶材との直接接触による境界摩擦, 雪粒と屋根蒙材とが接触して いない空隙部に融雪水が介在するために生ずる潤滑摩擦の 2 つの摩 擦現象が関与している。湿潤化が進行する過程における摩擦抵抗力 をこの $2 つ の$ 摩擦現象の混合摩擦として，その抵抗力を模式的に示 すと図一 8 となる。図のように, 乾燥状態の摩擦抵抗力は境界摩擦 による抵抗力 $a$ のみが作用する。滑雪界面が湿潤した状態になる と, 雪粒間あるいは雪粒と屋根葺材との接触摩擦部の空隙内に融雪 水が介在することによって，その水の粘着抵抗力 $b$ が付加作用す る。その空隙部全てが水で飽和した状態になるときに最大の摩擦抵 抗力となり，それ以上の融雪水が発生すると水は直接接触による境 界摩擦を減少させる作用をする。雪粒と屋根葺材との直接接触部が なくなると，融雪水が滑雪界面を満た寸状態となり，その水量増加 に伴って摩擦抵抗力はさらに減少する。

以上のような摩擦特性を基に前述した図一 5 ，6の結果を説明す ると次のようになる。滑雪界面付近の雪は，湿潤化することによっ て雪粒間あるいは雪粒と屋根葺材との粘着力が増加する。すなわち 融雪初期のW1から滑雪界面が湿潤化したW3までの状態では, 雪
が徐々に融雪することで滑雪界面付近の雪の含水量が上昇して，滑 雪に対する粘着抵抗力が増加するために動摩擦係数が増加してい る。また，W4の状態では十分な融雪水によって，雪水体の飽和する 含水量を越える湿潤状態になるために，その水は雪粒と屋根莫材と の直接接触の面積を減少させる作用をして，雪粒径の変化による動 摩擦係数への影響が小さくなっていると考える。粒径が 1 - $2 \mathrm{~mm}$ 程 度のざらめ雪 2 がしまり雪などの粒径が小さな雪質に比べて動摩擦 係数の増減が小さいことの要因として，ざらめ雪 2 の場合，雪粒径 が大きく毛管現象が発生し難いために, 雪の中に捕水できる水分量 が小さくなり滑雪界面が融雪水で満たされやすいことが挙げられ る。さらに，粒径が大きい場合において湿潤化に伴う雪粒間の粘着 力が小さくなることも，この要因と考えられる。図一7でみられた 湿潤の程度に応じて動摩擦係数が最大となる屋根萁材の表面粗さが 異なることの要因は，境界摩擦の抵抗力となる材料表面の凹凸部の 雪が融雪水で飽和するときに摩擦抵抗力が最大となることが考えら れる。すなわち, 平滑な屋根蕞材ではその状態となるのに必要な水 量が少なく，粗い材料では水量が多く必要となる。これらのことか ら，経時的に雪粒が粗大化する現象および滑雪界面が十分に湿潤す

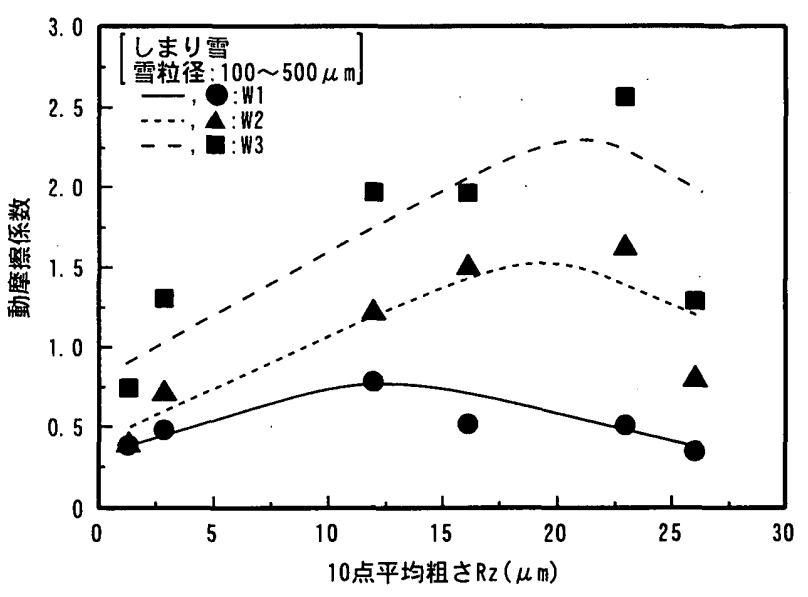

图一 7 屋根菆材の表面粗さと動摩擦係数との関倸

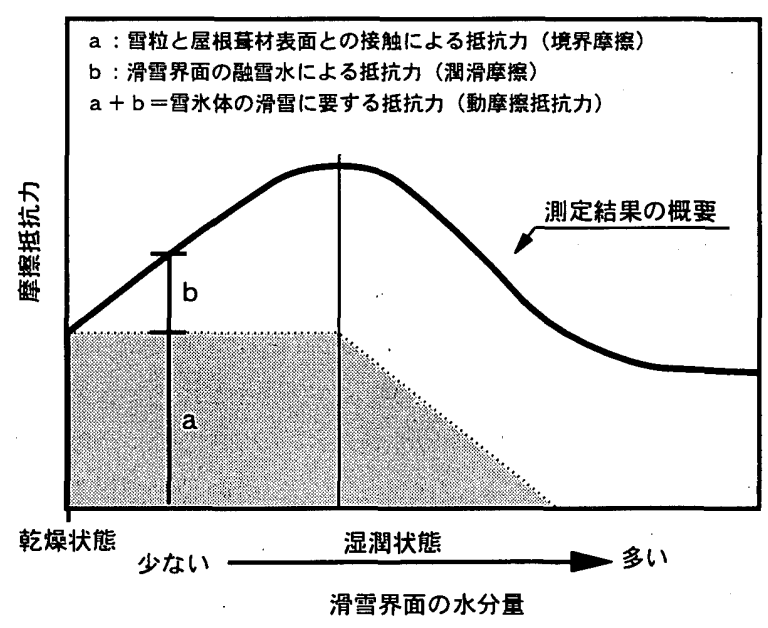

図一8 滑雪界面の湿潤化に伴う動摩擦抵抗力の変化 


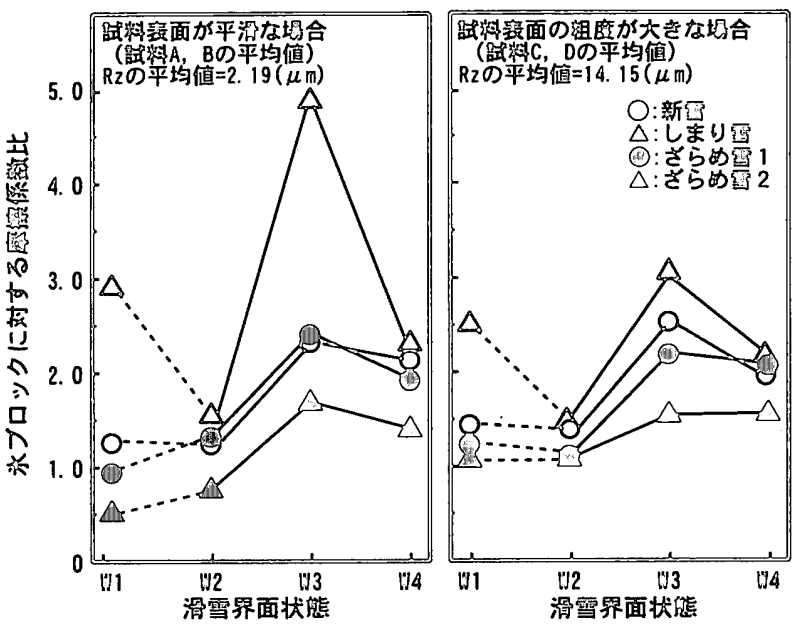

図一9 水ブロックとそれぞれの雪質との動摩擦係数の違い

ることは, 動摩擦抵抗力を減少させる効果を持っている。従って, 屋根雪の経時的な雪質変化は，滑雪の促進に有効な作用を及ぼすと 言える。

\section{（3）水ブロックを用いた滑雪抵抗力の評価}

屋根罟材の滑雪性能を評価する手法として，水ブロックを用いて 動摩擦係数を評価することは，雪水体の製作が比較的簡便であり， その物性が安定していること, さらには自然積雪のように採取期間 に左右されないことなどの利点がある。ここで, 屋根雪と屋根莫材 との界面が湿潤化してゆく過程における水ブロックと各雪質との動 摩擦係数の違いを整理すると図一9になる。なお, 図中の縦軸に示 す動摩擦係数比は，氷ブロックを基準とした場合の各雪質の場合の 比である。図のように，試料表面が平滑な場合におけるW3の状態を みると，しまり雪で水ブロックの 5.0 倍程度を示し，ざらめ雪 2 では 1.5倍程度となる。このように, 動摩擦係数は雪粒子の粗大化に伴っ て氷ブロックで得られる值に近づく傾向を示す。試料表面の粗度が 大きい場合についてみると，その動摩擦係数は小さくなるものの， 平滑な試料と同様の傾向となる。ここで, 融雪初期の状態である W1 では, 試料表面の粗度に関わらず，しまり雪の動摩擦係数が水ブロッ クに比べて大きくなる傾向がみられる。この要因としては，しまり 雪は比較的小さな雪粒子が密に配置されているので，融雪水の捕水 性が高く，滑雪界面が湿潤となるた如要する融雪量が他の雪質よ クも多くなることが考えられる。また，捕水している雪ブロックの 下面では，その雪粒子間の付着力が大きくなることも動摩擦係数が 大きくなる要因と考える。以上のように，水ブロックから得られる 動摩擦係数と経時的に変化する雪質の動摩擦係数とを比較すると, しまり雪のように雪粒子が小さく密に配置された雪質や融雪初期の 状態における動摩擦係数は，水ブロックの場合と比べてその差が大 きくなる。しかし，雪粒子が粗大化したざらめ雪 2 では動摩擦抵抗 力に及ぼす融雪水の影響が小さく，この雪質での動摩擦係数は水ブ ロックで得られる值に近くなることから，雪粒子が粗大化した状態 においては，氷ブロックを用いた滑雪性の評価が可能と考える。

\section{5.まと虭}

屋根上積雪荷重を制御する場合，屋根上に堆稓した雪を一定期間 内で規則的に排除する必要がある。本研究では，滑雪現象を利用し た方法で荷重制御する場合の基礎資料を提示することを目的に，屋 根上に積雪した後の一定期間における雪質変化が滑雪抵抗力に及ぼ 寸影響について検討した。その結果，屋根雪下層の雪粒は経時的に 粗大化し,その雪質は 1 週間程度で粒径 $1 \sim 2 \mathrm{~mm}$ 程度のざらめ雪と なることが観測できた。この現象による滑雪特性について評価した 結果，雪質変化に伴う滑雪抵抗力はしまり雪で最大となり，その雪 質では，滑雪界面の湿潤化の影響を大きく受ける。さらに，雪粒が 粗大化したざらめ雪になると, 動摩擦抵抗力は減少し, 滑雪界面の 湿潤化の影響が小さい。このように，しまり雪以上の雪粒径となれ ば，その雪粒が粗大化するに伴って滑雪抵抗力が減少することを考 えると, 屋根雪の経時的な雪質変化は滑落雪の促進に有効な現象と 考える。

今後は，滑雪現象を規則的に制御する手法として，屋根雪下層の 雪粒の粗大化を促進するために有効な小屋裏温度環境あるいは屋根 蔡材の表面特性などを明らかにする必要がある。

なお, 本研究の一部は, 1997年度文部省科学研究費基盤研究 $\mathrm{C}($ 代 表者：苫米地 司）で実施したものである。

\section{参考文献}

1）豊田裕道：園芸施設の積雪荷重見直しと新構造ハウスの傾向, 第12回展業 施設研究会, pp.25-40, 1997.7

2）會橋 重, 他 5 名：(仮称) 但馬ドームの積雪荷重の検討, 日本建築学会 学術講演梗概集 B-1, pp.119-120, 1997.9

3）日本建築学会編：昭和56年豪雪被害調查報告, pp.276-278, 1981.12

4）日本建築学会編：建築物荷重指針·同解説, pp.197-200, 1993.6

5）前田博司，他 3 名：平板上の自然䆏雪の滑雪性状について，第11回日本雪 工学会大会論文報告集, pp.35-38, 1994.11

6）苫米地 司，高會政寞，伊東敏幸：屋根蒙材の表面粗さが滑雷現像に及ほ す影響, 日本雪工学会誌, Vol. 12, No. 3, pp.3-9, 1996.7

7）伊東敏幸, 苫米地 司, 星野政幸：劣化した塗装鋼板の表面性状と滑雪性 について, 日本雪工学会誌, Vol. 10, No. 2, pp.2-10, 1994.4

8）渡辺正朋, 平井和蓄：屋根葺材と屋根雪の摩擦に関する研究，（その1） 主要な屋根茸材と水ブロックとの静摩擦, 日本雪工学会誌, 第 3 号, pp. $1-11,1987.6$

9）渡辺正朋，平井和喜：屋根龩材と壓根雪の摩擦に関する研究，(その2） 屋根茸材に対する雪氷の滑走速度および動摩擦, 日本雪工学会誌, 第 9 号, pp.4-15, 1988.12

10）山形敏明, 苫米地 司：屋根雪落雪事故の発生要因について, 第12回日本 雪工学会大会論文報告集, pp.35-38, 1996.1

11）竹中隆一,他 3 名：積霓寒冷地域における膜ド一ムの膜上䅡雪処理に関す る研究その 2 , 自然落雪と温風融雪の効果に関する解析, 第 9 回寒地技術 シンポジウム講演論文集, pp.7-12, 1993.12

12）苫米地 司, 他 3 名：屋根雪の滑雪現象に関する基礎的研究，日本雪工学 会誌, Vol.11, No.2, pp.2-9, 1995.4

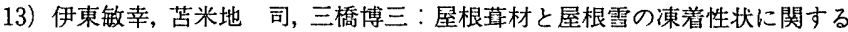
研究, 日本建築学会構造系論文集, 第470号, pp.43-51, 1995.4

14）前野紀一, 福田正巳編：基礎雪水学講座 I, 雪水の棈造と物性, 古今書院, pp.132-142

15）対馬勝年：水に浸った雪の粗大化, 日本雪水学会誌, 第40巻 4 号, pp.1-11, 1978.12

16）福沢卓也, 秋田谷英治：しもざらめ雪層の急速形成過程の観測, 低温科学, 物理編，第50輯，1991.11

（1997年 9 月10日原稿受理，1998年 3 月 9 日採用決定） 